\title{
Situación de Amado Nervo
}

El 27 de agosto de 1970 el mundo hispano recordó el centenario del nacimiento del poeta mexicano Amado Nervo, muerto el 24 de mayo de 1919. El año de su muerte su fama había llegado al pináculo; era el ídolo, entonces, tanto del gran público lector como de las minorías selectas. En Buenos Aires - residía en la región del Río de la Plata el año de su muerte- se le preconizó poeta máximo de América. Al morir, la estimación en que se le tenía quedó bien demostrada al ser enviado su cadáver del Uruguay a México en fragata de guerra escoltada por naves de la Argentina, México, Cuba y los Estados Unidos. Al sepelio, en la Rotonda de los Hombres Ilustres en la ciudad de México asistieron trescientos mil admiradores; algún orador les hizo ver que con la muerte de Nervo América perdía al poeta más hondo y más intimo; no pasa día ese año sin que aparezca en los diarios y revistas de América y España algún artículo, estudio o ensayo en homenaje póstumo. "Sus contemporáneos - dice uno de sus panegiristas - tal vez no nos damos cuenta de que hemos convivido con un genio; estábamos demasiado cerca de él, y la figura de los grandes hombres, como los grandes acontecimientos de la humanidad, deben ser contemplados de lejos, para apreciar sus proporciones". 1

Mas la fama es efímera. Al contemplar la obra literaria de Nervo desde lejos, como aconseja el panegirista, nos damos cuenta de que su valor, en vez de haber aumentado, ha disminuido. Nos proponemos en este ensayo, escrito para recordar el centenario de su nacimiento, examinar la situación del "fraile de los suspiros", como lo llamara Rubén Dario, y tratar de fijar su posición dentro del movimiento modernista hispanoamericano, a cuya corriente su obra pertenece.

La trayectoria poética de Nervo va, como en Dario, Lugones y Juan Ramón Jiménez, de la obra hermética a la obra abierta. En su primera época, en la época anterior a su viaje a París con don Justo Sierra en

* Con este trabajo y los documentos que publica Juan Loveluck en pp. 495-508. la R.I. se adhiere al centenario del nacimiento de Amado Nervo.

1 Amado Nervo y la crítica literaria. (México: Botas, s. f. [¿1919?], p. 35. 
1900, Nervo es modernista de capilla. Victoriano Salado Alvarez, en carta a Francisco M. de Olaguíbel, publicada en 1899 bajo el título "Los modernistas mexicanos", le dice: "Ha escuchado usted hasta ahora, en alabanza de sus versos, los pareceres de sus correligionarios y amigos, de los miembros de ese círculo apretado por pequeño, y aguerrido por militante, de que forma parte Tablada, el artista peregrino, y Nervo, el orifice exquisito". ${ }^{2}$

$Y$ es irónico que Nervo, acusado de escribir, en su última época, poesía fácil, poesía popular, poesía de almanaque, poesía - en una palabra- cursi, fuera por el mismo crítico tildado de hermético. "Ustedes -dice Salado Alvarez - los mexicanos 'modernistas' (creo que esa es la palabra) se dan a imitar frases, dicción, metro e ideas de los poetas franceses novisimos, y consiguen no sólo que el gran público no los entienda, sino que la pequeña minoría que lee moteje de no comprender su época" (Ibid., p. 4).

Es también irónico que la poesía de Nervo de esa etapa modernista fuera considerada cursi -contradictoriamente-- por el mismo crítico, quien en carta al autor de Perlas negras, subscrita en Guadalajara el 10 de febrero de 1898, dice: "Claro que los modernistas no son poetas autóctonos ni aborígenes; peto cursería por cursería, y afectación por afectación, prefiero la de los que cantan el zempoaxóchitl y asaltan la tribuna patriótica a la de los que vienen entreteniéndonos hace diez años con las penas de Manón, los placeres del barrio latino, los horrores del 'chat noir', los neurosismos y las picardias de las poseídas" (Ibid., p. 38).

Salado Alvarez, que se olvidaba o no sabía que Nervo también cantó lo nacional, pedía en 1898 que los modernistas cultivaran el tipo de poesía inspirada por la Revolución y que López Velarde habría de escribir entre 1916 y 1921. Pero cabe preguntar chubiera podido el autor de "La suave patria" escribir su poesía nacional, como la conocemos, sin la presencia de algunas obras de Darío, de Lugones y de Nervo? Como ha observado José Emilio Pacheco, con las poesías "La raza muerta", "La raza de bronce", el "Canto a Morelos" y "Guadalupe la chinaca" Nervo se adelanta al Chocano de Alma América, al Darío de Canto a la Argentina y al Lugones de Odas seculares e inicia un proceso

\footnotetext{
2 Victoriano Salado Alvarez, De mi cosecha (Guadalajara: Imp. de Ancira Hno. A. Ochoa, 1899), p. 2.
} 
de nacionalización del cosmopolitismo. ${ }^{3}$ Así, vemos que López Velarde, que llamó a Nervo "nuestro as de ases [...] el poeta máximo nuestro"," tiene con el nayarita una deuda que hasta nuestros días comienza a valorarse.

En algunas de sus poesías, que no son precisamente aquellas en que desarrolla temas nacionales, Nervo prefigura a López Velarde; en "Vieja llave" (de la colección En voz baja, París 1909), por ejemplo, la ima.. gen titular se convierte en símbolo emocional representativo de la añorada tranquilidad provinciana. Algunas partes del poema ya nos hacen pensar en el zacatecano:

Tu torcida arquitectura

es la misma del portal

de mi antigua casa oscura...

Es la misma de la ufana

y luminosa ventana

donde Inés, mi prima y yo

nos dijimos tantas cosas

en las tardes misteriosas

del buen tiempo que pasó...

"López Velarde -observa Manuel Durán- es hijo espiritual y heredero de Nervo, lo mismo que Nervo lo es de Gutiérrez Nájera. Melancolía, nostalgia, mezcla de erotismo y religiosidad, sensualidad vagamente culpable: todo ello es común a ambos poetas". ${ }^{5} \mathrm{Y}$ el propio López. Velarde nos habla de "el Nervo encantador que me sé de memoria, pleno, sobresaltado, místico, abundante de gracia, fiel a sí mismo, amartelado con cada creatura" (Ibid., p. 107).

Antes de visitar Europa Nervo escribió también algunas poesías paisajistas. En su primer libro, Perlas negras (1898), ya aparecen, como ha observado Ernesto Mejía Sánchez, ${ }^{6}$ algunas poesías paisajistas. $\mathrm{Y}$ antes de eso, en Mañana del poeta, que contiene composiciones escritas entre 1886 y 1891, recoge Méndez Plancarte una serie de "Cantos a la naturaleza". Es bien conocido el imaginativo soneto "El muecín". (de la

3 Antología del modernismo [mexicano] 2 tomos (México: UNAM, 1970),

4 Amado Nervo y la critica literaria, p. 107.

5 Manuel Durán, Gento y figura de Amado Nervo (Buenos Aires: EUDEBA, 1968), p. 115 .

'Conferencia sobre "Nervo y el modernismo", pronunciada en la Sala Manuel Ponce del INBA, el 3 de agosto de 1970. 
colección Poemas, París, 1901), que es, excepto por la transposición de las imágenes - la substitución de los motivos del cercano oriente por los de la provincia mexicana- para darle a la composición un aire exótico, modernista, un excelente ejemplo de síntesis entre la poesía paisajista mexicana tradicional y el modernismo hispanoamericano. En el siguiente cuarteto, a pesar del símil oriental, las imágenes evocan el paisaje americano:

Como egipcia columnata donde el aura veraniega finge trémolos medrosos, el palmar en la vecina hondonada se repliega. Todo es paz, la noche llega con la frente diademada por estrella vespertina.

Con este soneto Nervo rompe la tradición paisajista de Pagaza y Othón por medio de un simple procedimiento retórico: el uso del encabalgamiento, que da a la descripción un nuevo ritmo, un nuevo tono:

Cual nidada de palomas se acurruca, se repliega

en los flancos verdinegros de la plácida colina

el islámico poblado; más allá luce la vega

sus matices que semejan los de alfombra damasina.

Nervo, lo sabemos, no vuelve a escribir poesía nacional o paisajista. $\mathrm{Su}$ contacto con los escritores hispanoamericanos (Darío sobre todo), españoles (Unamuno especialmente) y franceses en Europa a partir de 1900 lo desvía hacia una nueva temática, una nueva modalidad formal y una nueva actitud ante el mundo. Abandona - y en esto se adelanta a González Martínez, el primer postmodernista- el preciosismo rubendariano para escribir, como él dijo, sin retórica, sin técnica, sin procedimiento, sin literatura. Su estética pasa a fundamentarse en un solo elemento, la sinceridad. Hay que observar, sin embargo, que escribir poesía sin retórica es otra forma de la retórica. Lo mismo ocurre, como ha visto Manuel Durán, en el desarrollo poético de Juan Ramón Jiménez. "La evolución del estilo de Nervo - dice- es, quizá, más profunda y sistemática que la de J. R. J., y ciertamente avanza hacia una creciente sencillez, hasta el punto de que, para Reyes, aquella poesia 'se encamina al silencio" (Ibid., p. 125).

En Europa, al abandonar Nervo la temática que había practicado en México, se acoge a dos fuentes de inspiración: la angustia personal (que como ha observado Alfredo Roggiano es uno de los signos del 
modernismo hispanamericano) y la filosofía. La nota personal, que nunca desaparece, predomina en la poesía escrita entre 1901 y 1912. De cste último año en adelante la nota filosófica desplaza a la personal. Estos cambios temáticos coinciden con cambios en la vida intima del poeta. El interés en los temas filosóficos, que ya era evidente en su obra juvenil, aumenta a partir de 1905, año de la muerte de su madre, ${ }^{7}$ y predomina después de 1912. En ese último año sufrió Nervo, como él mismo nos dice, la experiencia más espantosa de su vida, esto es, la muerte de su amada Ana Cecilia Luisa Dailliez. En carta a Luis Quintanilla y Fortuño, subscrita en Madrid —en donde ocurrió la muerte de Ana- el 30 de enero de 1912, el poeta le dice a su amigo: "Mil gracias por el libro de Remi de Gourmont. Cuando encuentres algo que sea de marcada tendencia espiritualista, algo que me haga pensar en que no somos sólo esa pobre cosa putrefacta que se deshace en los cementerios, algo que me nutra en la idea de que mi Ana vive aún en alguna forma y que me ama y me espera, mándamela". ${ }^{8}$ De aquí en adelante su poesía ha de reflejar ese interés en el más allá. Su gran angustia, a la vez, le hace simpatizar con los que sufren y para ellos escribe poesía llena de resigzación y renunciamiento, con el propósito de consolarlos. Y para consolarse a sí mismo escribe La amada inmóvil (publicada en 1920), el libro más íntimo con que cuenta la poesía mexicana. Este libro, dice José Emilio Pacheco, "constituye un intermedio de angustia que lo afirma en su búsqueda de la serenidad. Aquí no hay distancia entre el hombre que sufre y la mente que crea. Su imposibilidad de hallar consuelo es tan sincera que uno se siente incómodo al juzgar como obra literaria estos poemas (Nervo, en efecto, no quiso publicarlos y aparecieron póstumamente)" (Ibid., II, 5).

El cambio en la temática de Nervo coincide con un cambio en su estética. O tal vez sería más acertado decir que, al seleccionar temas distintos, el poeta se ve en la necesidad de cambiar su estética. El proceso en Nervo hacia la poesía desnuda (esto es, sin adornos retóricos) se inicia en algunas partes de La hermana agula (1901), se intensifica en algunas de las poesías recogidas en el tomo En voz baja (1909) y predomina en todo lo escrito a partir de Serenidad (1914). En una poesía recogida en Los jardines interiores (1905) pero escrita con an-

7 Nervo había vuelto a México en 1904 . Su madre falleció el 12 de diciembre de 1905 , dos meses después de que el poeta regresara a España como segundo secretatio de la Legación de México en Madrid. p. 77.

8 Amado Nervo, un epistolario inédito (México: Imp. Universitaria, 1951), 
terioridad, todavia encontramos estos versos, que reflejan la estética modernista:
Yo trabajo, mi fe no se mitiga
$y$, troquelando estrofas con mi sello,
un verso acuñaré del que se diga:
Tu verso es como el oro sin liga:
radiante, dúctil, poliforme y bello.

Pronto, sin embargo, ha de abandonar esa posición. El cambio fue debido, como ya hemos dicho, a las experiencias sufridas en carne viva. Pero también, sin duda, a la influencia de Unamuno, quien criticaba a los modernistas hispanoamericanos por haberse entregado en cuerpo y alma a la literatura francesa. "Después de Dario - dice Durán- las grandes influencias son para él, las de los irracionalistas -en mayor o menor grado- es decir, las de Unamuno, Maeterlink, Bergson" (Ibid., p. 47). Bien sabido es que Nervo leyó a Unamuno algunas de las poesías de la colección En voz baja y que éste las elogió en conocido Prólogo y en algunas cartas. Ernesto Mejía Sánchez se ha ocupado de las relaciones entre Unamuno y Nervo. ${ }^{9}$

Para 1914 el cambio en la estética del mexicano se ha cumplido. En Serenidad, de ese año, se encuentran estos versos:
Yo no sé nada de literatura, ni de vocales átonas o tónicas, ni de ritmos, medidas o cesura, ni de escuelas (comadres" antagónicas), ni de malabarismos de estructura...

Y todavía va más lejos; en uno de sus últimos libros, Elevación (1917), encontramos el siguiente "Amén": "Lector: Este libro sin retórica, sin procedimiento, sin técnica, sin literatura, sólo quiso una cosa: elevar tu espíritu. ¡Dichoso yo si lo he logrado!

Esta poesía postmodernista de Nervo es la más divulgada y por la cual se le ha juzgado. Es, también, la que más ha sufrido los rigores del tiempo. Al abandonar la troquelada imagen modernista y escribir

\footnotetext{
9 Ernesto Mejía Sánchez, "De Unamuno a Nervo", Anuario de Letras, VI $(1964), 203-235$.
} 
sin retórica, sin literatura, queda al descubierto la idea del poema, que no siempre es feliz o profunda. Nervo no era filósofo; era poeta. Durán lo llama "el más filósofo, el más metafísico de los poetas modernistas". En cambio, a Unamuno lo llama "el más poeta de los filósofos de su época" (Ibid., p. 41).

Si bien Alfonso Méndez Plancarte ve en esta poesía pensativa y desnuda de Nervo un anticipo de la poética de Machado, Unamuno, Juan Ramón Jiménez y Pedro Salinas, ${ }^{10}$ hay que confesar que, al desnudar su poesía, el poeta no logró retener el valor lírico de su época anterior. El primero en notar este decaimiento fue Enrique González Martínez. Al reseñar el libro Elevación el poeta del buho escribió: "Estas filosofías categóricamente afirmativas, hechas en verso, por más libre de tutelas retóricas y estéticas que se les suponga, son poco poéticas". ${ }^{11}$ ¿Por qué - nos preguntamos- han sido tan populares estas poesías filosóficas de Nervo? Tal vez por la naturaleza del mensaje y la facilidad con que el poeta podía glosar sus lecturas sobre filosofía y forjar versos fáciles de recordar. ¿Quién que haya leído Elevación no recuerda los siguientes?:

Si una espina me hiere, me aparto de la espina ... pero no la aborrezco.

Si eres bueno, sabrás todas las cosas, sin libros...

Es tan llano entenderlo todo, cuando lo oímos con humildad.

En Plenitud (1918) Nervo da un paso más en su evolución estética: abandona el verso para expresar sus pensamientos y glosar sus lecturas en prosa, si bien en una prosa difícil de distinguir de su última poesía. En la forma, no encontramos gran diferencia entre los versos citados y estas prosas:

Siempre que haya un hueco en tu vida, llénalo de amor.

10 Amado Nervo, Primavera y flor de su lirica. Prólogo y selección de Alfonso Méndez Plancarte (Madrid: Aguilar 1952), p. 38.

11 Enrique González Martínez, "Amado Nervo, el poeta", en Obras completas de Amado Nervo, XXIX (Madrid: Biblioteca Nueva, 1928), p. 227. 
El proverbio persa dijo: "no hieras a la mujer ni con el pétalo de una rosa".

Yo te digo: "no la hieras ni con el pensamiento".

Vale más errar creyendo que errar dudando.

En su siguiente libro, El estanque de los lotos (1919), Nervo vuelve al verso, pero lo llama "prosa rimada". Aquí ya no hay ninguna preocupación por la forma; todo el interés se centra en la expresión de pensamientos filosóficos y morales. A través de estas páginas encontramos citas y glosas de varios filósofos. En "Los manantiales" el poeta abandona todo principio estético y nos of rece una guía para la lectura:

Lee los libros esenciales, bebe leche de leones; gusta el vino de los fuertes: tu Platón y tu Plotino, tu Pitágoras, tu Biblia, tus indios inmemoriales; Epicteto, Marco Aurelio... ¡Todo el frescor cristalino que nos brindan los eternos manantiales!

Si González Martínez había rechazado la poesía filosófica de Nervo, los "Contemporáneos" rechazan también su poesía personal; y la rechazan precisamente por su tono confidencial ("Alma, ven a mi alma sin ruido, que te quiero decir, así, al oído..." por "su impúdica desnudez y sus peripecias sentimentales". Nervo, nos dicen, deja que la vida ahogue al arte, que la confidencia sustituya a la estética. Desgraciadamente, una crítica ciega, superficial, ha seguido la pauta trazada por los "Contemporáneos" y ha condenado la obra de Nervo, a veces sin haberla leído. Ya uno de los más destacados poetas del grupo, Xavier Villaurrutia, había presentido la tendencia a negar todo valor a la obra del nayarita: "Es un lugar común -o debe serlo- que la generación 'Contemporáneos' puntualizó la necesidad de colocar a Nervo en su verdadero sitio, reduciéndolo, como al propio Nervo le hubiera gustado, a su auténtica y mensurable estatura. Se había exagerado la importancia y sobre todo la profundidad de su poesía, lo que no quiere decir que ahora se deba exagerar negándole importancia y profundidad". ${ }^{12}$

12 Reseña de B. Ortiz de Montellano, Figura, amor y muerte de Amado Nervo (México: Ediciones Xóchitl, 1943), en El hijo pródigo, II, 9 (dic. 1943), p. 218. 
A pesar del consejo de Villaurrutia, la siguiente generación no sólo le niega importancia y profundidad a la obra de Nervo, sino que se niega a leerla, ya que la considera carente de todo valor estético. El juicio de José Luis Martínez es representativo de la actitud del grupo ante la obra del fraile de los suspiros: "Seguirá nuestro Amado Nervo -dice Martínez- en las bibliotecas rosas por sus incapacidades insuperables; por su deplorable inclinación a la chabacanería, por su gusto dudoso, por su carencia de profundidad y de misterio, por su falta de poder para desvelarnos radicalmente $[\ldots]$ y sobre todo, porque no tiene una dimensión más allá de su eficacia comunicativa". ${ }^{13}$

Si esa apreciación de la poesía de Nervo es la verdadera, ¿son equirocados, entonces, los juicios favorables expresados por Unamuno, Reyes, Dario, Juan Ramón Jiménez, López Velarde y Américo Castro? ¿Fue insincero Darío al dedicarle estas palabras?: "En verdad os digo que muy pocos de nuestros líricos le igualarían en exquisitez y ninguno en sinceridad $[\ldots] \mathrm{Ha}$ sido un admirable sincero y por eso mismo un admirable poeta". ${ }^{14}$ Sabemos que Darío era amigo íntimo de Nervo. No así Juan Ramón Jiménez, quien dijo del mexicano: "Yo siento por Amado Nervo ese cariño que a veces tiene el alma por una rosa, por un ruiseñor. Hay poetas a quienes amo con la frente; a éste lo quiero con el corazón". ${ }^{15}$ Así como no podemos aceptar los juicios de Ortiz de Montellano o de Martínez, tampoco podemos aceptar (si se refieren a la obra total de Nervo) los de Unamuno, Dario o Juan Ramón Jiménez. Como poeta Nervo tuvo grandes momentos y grandes caídas. ${ }^{10}$ Mas eso no indica que debemos olvidarnos de toda su obra lírica, como se ha intentado hacer. Si apartamos la poesía seudo filosófica y la que cae en la confidencia, todavía queda buen número de composiciones dignas de figurar entre las mejores que la poesía hispana ha producido. En su mejores momentos Nervo supo dar profundidad a su poesía, lo mismo que revestirla en formas apropiadas. "Méjico - dice Américo Castro- nos ha dado en Nervo un poeta de profundas resonancias: en su estilo percibimos el latido de lejanas y misteriosas civilizaciones". ${ }^{17}$

¿Tuvo Nervo conciencia de que su obra tendría que pasar por el túnel del olvido? Sin duda alguna. Eso es lo que nos revela la siguiente

13 José Luis Martínez, Literatura mexicana siglo XX, 1910-1949 (México: Robredo, 1949), p. 153.

14 Citado por Méndez Plancarte en Primavera y flor..., p. 37.

15 Ibid., p. 41.

16 No podemos aquí juzgar a Nervo como prosista, tarea que nos reservamos para un futuro trabajo.

17 América Castro, Iberoamérica (New York. 1954), p. 211. 
cita: "Dentro de veinte años - dice- nuevos poetas, más sutilizados [...], cantarán cosas junto a las cuales nuestros pobres modernismos de ahora resultarán ingenua senectud. $Y$ así sucesivamente". ${ }^{18}$ En lo único que se equivocó Nervo fue en el número de años que habían de pasar para que los nuevos poetas lo desterraran del parnaso mexicano. Jorge Cuesta en 1928, esto es, nueve años después de la muerte del poeta, rechaza públicamente, en su famosa Antología de la poesía mexicana contemporánea, la obra de Nervo. Desde ese año en adelante, la estrella del nayarita comienza a descender. Hacia 1950, como ha observado José Emilio Pacheco - tal vez pensando en el juicio de José Luis Martínez- la reputación poética de Nervo llegó a su punto más bajo. En 1960 nosotros terminábamos un ensayo sobre Nervo con estas palabras: "El gran número de ediciones de las obras de Nervo nos indica que su poesía es aún popular entre [el] gran público. ¿Mas recobratá - nos preguntamos - la admiración de las minorías selectas?" 19 Los trabajos sobre Nervo publicados en los últimos diez años indican que nuestra pregunta puede hoy ser contestada afirmativamente. Con la publicación, en 1962, de sus Obras completas en dos tomos con sendos estudios de Francisco González Guerrero y Alfonso Méndez Plancarte, ${ }^{20}$ la revaloración de Nervo queda inaugurada. El creciente interés de la crítica seria lo demuestra la publicación en Buenos Aires en 1968 del libro de Manuel Durán, en el cual se hace una justiciera apreciación de la poesía y la prosa del mexicano. Aún más recientes son los juicios de José Emilio Pacheco, Ernesto Mejía Sánchez, Ramón Xirau, Carlos Pellicer, Salvador Reyes Nevares y otros destacados críticos y escritores, quienes se han ocupado de hacerle justicia. Nervo, sin duda alguna, tenía capacidad para captar y expresar nuevos temas con profundas resonancias. $\mathrm{Su}$ voz fue primero (durante su período modernista) como lluvia de diamantes en azul terciopelo; y después, como soplo de viento que solloza en la torre. Sirvan estas notas para recordarle en el centenario de su nacimiento.

Urbana, Illinois

LUIS LEAL

18 Amado Nervo, Obras completes (Madrid: Aguilar, 1962), II, 399.

19 Luis Leal, "La poesía de Amado Nervo: a cuarenta años de distancia", Hispanid, XLIII, 1 (march, 1960), 47.

20 Madrid: Aguilar, 1962 (2 tomos). 